\title{
Defining correct dormancy class matters: morphological and morphophysiological dormancy in Arecaceae
}

\author{
Ganesh K. Jaganathan ${ }^{1}$ (D)
}

Received: 14 August 2020 / Accepted: 5 October 2020 / Published online: 14 October 2020

(C) INRAE and Springer-Verlag France SAS, part of Springer Nature 2020

\section{- Key message}

Dormancy in Arecaceae diaspores is due to underdeveloped embryos, therefore, morphological dormancy or morphophysiological dormancy. Consequently, claims such as external seed structures inhibit germination, embryos are fully developed at maturity, and underdeveloped embryo is not a form of dormancy are rejected, because embryo size of the diaspore at the time of dispersal was not taken into consideration. The re-classification proposal for moving morphological dormancy into non-dormancy is also discouraged. This is owing to the fact that when both morphological dormancy and non-dormant seeds are placed under conditions suitable for germination, those with morphological dormancy do not germinate immediately due to time needed for growth of the embryo, whereas non-dormant seeds can germinate quickly. The implications of correctly defining dormancy class are important, for researchers working with seeds at various levels from forestry to molecular biology.

With 2600+ species, palms constitute an essential component of tropical and sub-tropical biodiversity (Kissling et al. 2019). The life cycle of long-lived palms starts with diaspores, which differ considerably in size, shape, and color (Broschat et al. 2014; Corner 1966; Mabberley 2017; Tomlinson 1990). Typically, the dispersal unit of palms is a berry or fibrous drupe, which encompasses fibrous mesocarp, a thick endocarp, a fleshy nutritious endosperm, and a small embryo (Tomlinson 1990). It is well known (or inferred) that mostperhaps all - palm diaspores have an underdeveloped embryo, c. $>10 \%$ of the overall diaspore size, at the time of dispersal (Baskin and Baskin 2014b; Martin 1946; Tomlinson 1990). This feature - termed as morphological dormancy-means that embryos require time for the embryo to differentiate and grow inside the diaspores before germination occurs, which is usually within 30 days after dispersal (Baskin and Baskin 2004; Finch-Savage and Leubner-Metzger 2006; Nikolaeva 1969; see Fig. 1). However, most Arecaceae species have been reported to have morphophysiological dormancy, wherein the underdeveloped embryos also have a physiological

Handling Editor: Erwin Dreyer

Ganesh K. Jaganathan

jganeshcbe@gmail.com

1 Institute of Biothermal technology, University of Shanghai for Science and Technology, Shanghai 200093, China constraint either due to a hormonal imbalance or inability of the embryo to push through the hard endocarp, i.e., physiological dormancy, which requires both growth of embryo and alleviation of physiological dormancy before germination (Baskin and Baskin 2004; Finch-Savage and LeubnerMetzger 2006; Fig. 1).

Due to decades of research, there is an abundant literature on germination ecology of palms suggesting that germination requires several months to years (Baskin and Baskin 2014a, b). However, there are also a few studies that show that germination can be completed within 30 days (see reviews in Broschat et al. 2014; Koebernik 1971; Orozco-Segovia et al. 2003). The understanding that growth of the underdeveloped embryo and germination require a long period of time led Pérez (2009) to conclude that seeds of most of the Arecaceae species display morphophysiological dormancy, whereas few species have morphological dormancy. Despite this conclusion and clarification of why other forms of dormancy might be absent, many studies continued to report various forms of dormancy in palms. Subsequently, a more detailed synthesis was presented by Baskin and Baskin (2014a), who showed that $10 \%$ of the palms have morphological dormancy, and the remainder has morphophysiological dormancy. Consensus is growing that a water-impermeable seed coat, i.e., physical dormancy and combinational dormancy (Fig. 1) arising from the combination of impermeable seed coat and physiological dormancy of the embryo, i.e., physical 
Fig. 1 Depiction of seed dormancy classes originally developed by Nikolaeva (1969) and refined by Baskin and Baskin (2004). The reason for dormancy is shown in yellow. E, embryo; End/Cot, endosperm/cotyledon; $\mathrm{SC}$, seed coat

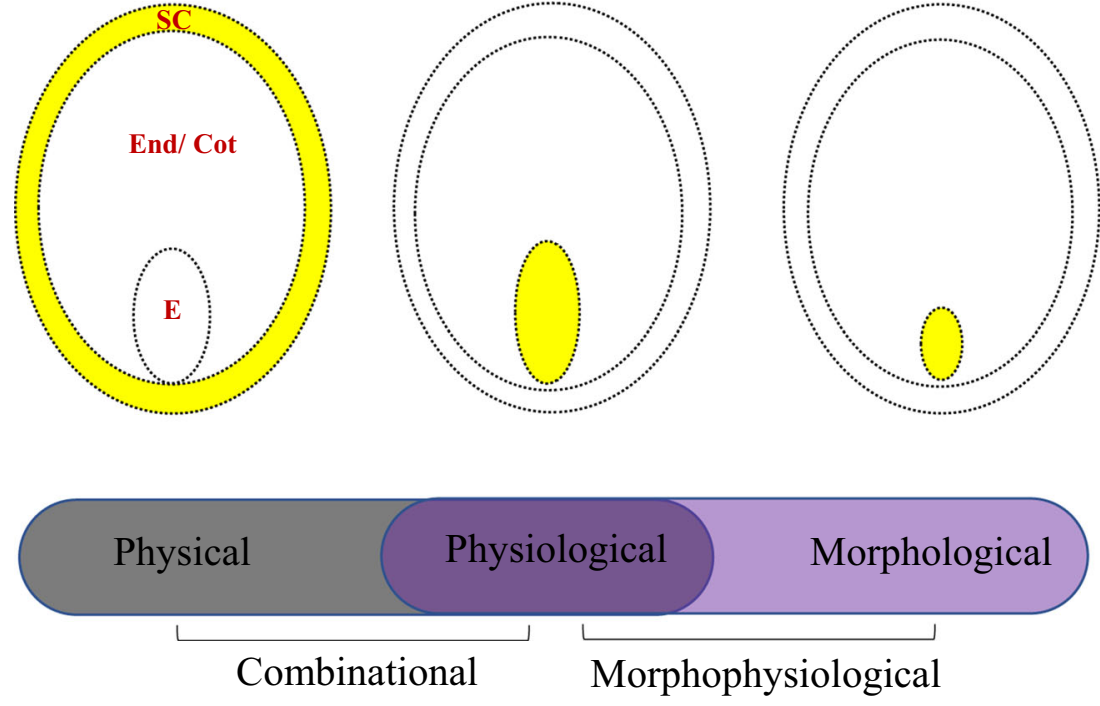

Combinational Morphophysiological dormancy + physiological dormancy, is absent in palms (e.g., Carvalho et al. 2015). However, many recent studies still conclude that palm diaspores have physiological dormancy or use terms such as embryonic dormancy (Nazário et al. 2017), physiological and physical dormancy (Medeiros et al. 2015), and even in some cases the seeds are reported to be dormant due to constraint resulting from the operculum (Moura et al. 2019). Further, there is disagreement as to whether morphological dormancy should be considered as a form of dormancy or be reclassified as an absence of actual dormancy (Mazzottini-dos-Santos et al. 2018; Visscher et al. 2020). The purpose of this opinion paper is to show, with some recent examples, that dormancy class in Arecaceae species is still entirely misrepresented or misinterpreted.

\section{Do palm diaspores have only physiological dormancy? No}

A more conspicuous problem with palm diaspore studies in the laboratory is the way seeds are handled from time of collection until initiation of experiments. It has been previously shown that this post-dispersal storage at certain temperature promotes after-ripening (Carpenter 1988; Meerow and Broschat 1991). In palm species, postdispersal storage of diaspores in the natural environment or at low temperatures, e.g., $8{ }^{\circ} \mathrm{C}$ (see Table 1 ), are conducive for embryo growth and breaking of physiological dormancy. These conditions mimic warm stratification or cold stratification typically applied to break simple or complex morphophysiological dormancy (Baskin and Baskin 2014a; Baskin and Baskin 2004). As it has been repeatedly pointed out, concluding absence of morphological dormancy or morphophysiological dormancy based on culturing excised embryos in a nutrition-rich medium does not accurately represent the dormancy class in palms (Baskin and Baskin 2014a; Broschat 1998; Nagao et al. 1980; Pérez 2009). Diaspores of Attalea vitrivir Zona (Neves et al. 2013), Acrocomia aculeata Lodd. ex Mart. (Ribeiro et al. 2012), and Butia capitata (Mart.) Becc. (Oliveira et al. 2013) collected in Brazil were reported to have physiological dormancy, presumably based on the excised embryo growing immediately. A post-maturation storage time may have allowed the embryo to grow and reach full size, before the endocarps were removed, further adding confusion with regard to dormancy classification (Table 1). Interestingly, Carvalho et al. (2015) assumed that the absence of morphological dormancy or morphophysiological dormancy reported in A. vitrivir, A. aculeate, and $B$. capitate from Brazil might be due to the fact that the difference is seed collection location. Hence, to close the argument, they collected diaspores of all three species growing in the cerrado biome in the northern region of Minas Gerais State, Brazil, and concluded that all the three species have physiological dormancy. However, in their study, all diaspores were stored for more than 1 month presumably at room temperature, which may have been sufficient time for embryo growth or physiological dormancy alleviation (see Fig. 1 in Carvalho et al. 2015). This would have allowed the seeds to germinate when endocarps were removed. Further, their study does not take embryo size at the time of dispersal into account.

More notably, misrepresentation of dormancy class in at least some of the Brazilian palm species has created further confusion in subsequent studies conducted on species in the region. Many other authors believe that dormancy in Brazilian palm species is caused by the constraint of the operculum, e.g., Mauritia flexuosa L. f. (Moura et al. 2019), B. capitata 
Table 1 Recent studies reporting dormancy other than morphological dormancy or morphophysiological dormancy in palms and their post-dispersal storage duration and conditions

\begin{tabular}{|c|c|c|c|c|}
\hline Species & $\begin{array}{l}\text { Collection } \\
\text { site }\end{array}$ & $\begin{array}{l}\text { Post-maturation storage } \\
\text { duration and conditions }\end{array}$ & Dormancy class reported & Reference \\
\hline $\begin{array}{r}\text { Acrocomia } \\
\text { aculeate }\end{array}$ & Brazil & $\begin{array}{l}1 \text { month, room } \\
\text { temperature }\end{array}$ & Physiological dormancy & $\begin{array}{l}\text { Carvalho et al. } \\
\text { (2015) }\end{array}$ \\
\hline Attalea vitrivir & Brazil & $\begin{array}{l}1 \text { month, room } \\
\text { temperature }\end{array}$ & Physiological dormancy & $\begin{array}{l}\text { Carvalho et al. } \\
\text { (2015) }\end{array}$ \\
\hline Butia capitata & Brazil & $\begin{array}{l}1 \text { month, room } \\
\text { temperature }\end{array}$ & Physiological dormancy & $\begin{array}{l}\text { Carvalho et al. } \\
\text { (2015) }\end{array}$ \\
\hline Butia capitate & Brazil & $\begin{array}{l}15 \text { days (and then } \\
\text { unknown period), room } \\
\text { temperature }\end{array}$ & Physiological dormancy & $\begin{array}{l}\text { Souza Dias } \\
\text { et al. (2018) }\end{array}$ \\
\hline $\begin{array}{l}\text { Mauritia } \\
\text { flexuosa }\end{array}$ & Brazil & 6 months, $20^{\circ} \mathrm{C}$ & $\begin{array}{l}\text { Dormant (due to } \\
\text { operculum) }\end{array}$ & $\begin{array}{l}\text { Moura et al. } \\
\text { (2019) }\end{array}$ \\
\hline $\begin{array}{l}\text { Pseudophoenix } \\
\text { ekmanii }\end{array}$ & $\begin{array}{r}\text { Dominican } \\
\text { republic }\end{array}$ & $\begin{array}{l}\text { More than } 1 \text { year } \\
\text { (unknown and } 15^{\circ} \mathrm{C} \text {, } \\
15 \% \mathrm{RH} \text { ) }\end{array}$ & $\begin{array}{l}\text { Morphological dormancy, } \\
\text { morphophysiological } \\
\text { dormancy }\end{array}$ & $\begin{array}{l}\text { Visscher et al. } \\
\quad(2020)\end{array}$ \\
\hline $\begin{array}{l}\text { Syagrus } \\
\text { coronata }\end{array}$ & Brazil & Not known & Physiological and physical & $\begin{array}{l}\text { Medeiros et al. } \\
\text { (2015) }\end{array}$ \\
\hline
\end{tabular}

(Souza Dias et al. 2018), or mesocarp, i.e., pulp, e.g., Syagrus coronata Becc. (Medeiros et al. 2015). In M. flexuosa, dormancy break was reported to occur after removing the operculum (manually), which immediately triggered germination (Moura et al. 2019). Likewise, Souza Dias et al. (2018) articulated 'As the seeds of B. capitata show pronounced dormancy, a dormancy-breaking treatment was performed on half of the seeds (consisting of removing the operculum under semiaseptic conditions, taking care to guarantee embryo integrity)', thus clearly indicating that dormancy is due to the presence of the operculum. However, these statements do not explain how dormancy is broken in the seeds found in the natural environment, because operculum removal occurs from outside the diaspore. Additionally, what is the role of such kind of dormancy in regulating germination timing for the seeds present in soil seed banks? Thus, it is unclear why dormancy should result from the presence of the operculum. However, it is more likely that the embryos lack strength to push out the operculum, which is evidence in support of physiological dormancy (sensu Baskin and Baskin 2004).

In a 2-year field and laboratory study using seeds of Butia odorata (Barb.Rodr.) Noblick collected from Patos Lagoon, Brazil, Schlindwein et al. (2019) showed that diaspores need cold stratification, followed by warm stratification for germination. Their results suggested that diaspores stored at $10^{\circ} \mathrm{C}$ for 3 months followed by exposure to summer temperatures can break dormancy, and any failure of germination in the first summer caused the diaspores to re-enter dormancy and germinate in the second summer, indicating dormancy cycling. This result also suggests that morphological dormancy was broken first or both physiological dormancy and morphological dormancy break occurred together, and the physiological dormancy cycles between dormant and non-dormant state.
However, those authors concluded that the seeds have only physiological dormancy. Nevertheless, Baskin and Baskin (2014a) consider that embryo of palm seeds to be underdeveloped and report the common presence of a morphological component to seed dormancy in the Arecaceae family. Whether or not palm seeds also have this morphological component in their dormancy status depends on the criterion used to define germination. If we consider radicle emergence, instead of protrusion of the cotyledonary petiole (common germination mark for palm seeds), as a definition for germination, we should then classify seed dormancy of $B$. capitata and $B$. odorata as 'non-deep morphophysiological'.

Without exceptions, the studies listed in Table 1 accept the presence of physiological dormancy in palms regardless of germination type, i.e., remote-tubular, remote-lingular, and adjacent-lingular (Henderson 2006), which was later adopted by Pérez (2009) and Baskin and Baskin (2014a). However, recognizing whether the species have an underdeveloped embryo at the time of dispersal, which develops into a fully grown embryo with physiological dormancy (or lack thereof), would require a different criterion to define 'seed germination'. This argument that the way we consider germination could determine how we define dormancy is unsound, especially due to a lack of studies on embryo growth prior to germination. Quite simply, if the palm diaspores reported to have physiological dormancy also have an underdeveloped embryo, then those species have morphophysiological dormancy. For example, embryo size of Pritchardia remota Beec. at the time of seed dispersal was an average of $3.9 \mathrm{~mm}$, which increased to an average of $6.2 \mathrm{~mm}$ during operculum displacement and then to an average of $10.6 \mathrm{~mm}$ during radicle emergence, given that the seeds also have physiological dormancy, thus showing presence of 
morphophysiological dormancy (Pérez et al. 2008). Hence, regardless of the criteria used for classifying germination in palms, including the incorporation of embryo size into the dormancy classification, is essential. Clearly, there is no shortage of studies displaying underdeveloped embryo visually (Mabberley 2017; Martin 1946; Riffle et al. 2012). However, the depiction of internal structures, particularly of the embryo, is currently unavailable for studies claiming dormancy other than morphological dormancy or morphophysiological dormancy in palms, to make a meaningful conclusion about the dormancy class. Nonetheless, the results reported for B. capitata (see Fig. 1A in Souza Dias et al. 2018) unequivocally illustrate the presence of an underdeveloped embryo.

The issue of post-dispersal storage is very important in palms because the seeds classified as morphological dormancy, due to the immediate growth of embryo when tested in the laboratory, might also have physiological dormancy, which could have been alleviated during post-maturation storage, or in embryos that grow during storage. However, the extent to which postmaturation storage might affect assigning diaspores to morphological dormancy or morphophysiological dormancy cannot be explored, particularly in the earlier studies, due to the shortage of details presented in those studies (e.g., Koebernik 1971). According to Baskin and Baskin (2014a), seeds with morphophysiological dormancy conditions involved in breaking morphological dormancy and physiological dormancy vary between species and the environmental conditions that promote embryo growth and break physiological dormancy could be the same or differ. Further, in some species, physiological dormancy is broken and then embryo growth occurs, i.e., alleviation of morphological dormancy. This case has been reported in palms, e.g., Pritchardia remota (Pérez et al. 2008), whereas in other species, physiological dormancy and morphological dormancy are broken at the same time. Furthermore, morphological dormancy break happens during physiological dormancy break, i.e., physiological dormancy break occurs and then the embryo grows, followed by further physiological dormancy loss. However, early interest in palm dormancy centered around promoting germination by breaking dormancy (Broschat and Donselman 1987; e.g., Carpenter et al. 1993; but see Hussey 1958; Nagao et al. 1980); the shift towards understanding germination ecology of palms is gaining impetus (Baskin and Baskin 2014a). More ecologically meaningful studies are expected to reveal the events happening in palm diaspores from dispersal to germination under natural conditions.

\section{Should we reclassify morphological dormancy as non-dormant? No}

There seems to be some confusion about whether morphological dormancy is really a form of dormancy. Working with
Attalea vitrivir, Acrocomia aculeata, and Butia capitata collected from Brazil and stored for up to 30+ days before experimentation, Mazzottini dos Santos et al. (2018) presented evidence for embryo growth inside the diaspores when subjected to germination. Despite this proof, those authors concluded that 'Embryo growth inside non-germinated seeds of A. aculeata and, in isolated cases, identified by the frequency distribution for B. capitata, can be interpreted as evidence of morphophysiological dormancy'. Further, they stated '... moderate and relatively fast growth (of the embryo) observed in the present study is related to the natural propensity for embryos to grow, as shown by the high germinability of seeds that had their opercula removed'. Similarly, in Pseudophoenix ekmanii Burret, a critically endangered species from the Dominican Republic, Visscher et al. (2020) recently reported that seeds started to germinate as early as 13 days when incubated at $30^{\circ} \mathrm{C}$, which was the temperature in the soil at the time of dispersal. Seed germination occurred between 30 and 82 days. This led them to assume that their seed lot had a cohort of morphological dormancy and morphophysiological dormancy seeds. Further, they argued that morphological dormancy should be reclassified as 'non-dormant' due to the continuous development of the embryo, i.e., there was no arrest of growth after dispersal, as the definition for dormancy indicates 'not active growing'. Nevertheless, the seeds used in their study were stored at different conditions for more than 1 year before being used in the experiments, which might trigger embryo growth inside the seed or even alleviation of physiological dormancy. Consequently, when water was imbibed, a small proportion of the seeds readily germinated, with a vast majority germinating after 30 days. Moreover, seeds from the same lot incubated at $20^{\circ} \mathrm{C}$ and required 30 days to the first germination. Thus, it is not known if the alleviation of physiological dormancy occurred first, followed by embryo growth indicating the presence of morphophysiological dormancy.

However, if defining (seed) dormancy as the absence of continuous growth even inside the seeds is a useful approach, then the same argument could be also extended for physiological dormancy, where the molecular changes continue to occur. Indeed, there is evidence to show that numerous processes including abscisic acid level changes, expression of specific genes, continue to occur in physiological dormancy seeds (Bewley et al. 2013; Finch-Savage and Leubner-Metzger 2006; Long et al. 2015; Vleeshouwers et al. 1995). The increase in embryo size due to continuous growth or the molecular changes leading to dormancy breaks that are all chains of events happening in dormant seeds. In either case, germination, i.e., protrusion of embryo, does not occur even if the appropriate temperature, water, and light are available, which would promote germination in non-dormant seeds. Thus, a significant difference between species with morphological dormancy and non-dormant species is that seeds with 
morphological dormancy do not germinate even in the appropriate conditions. Thus, this possibly allows secondary movement of 'dispersal units' while the embryo is still growing inside the seed. In contrast, non-dormant seeds possibly could begin to germinate at the first opportunity when suitable conditions, particularly water, temperature, and light, are present. The developed radicle develops and the roots are anchored into the soil, which eventually prevent further movement of seeds (Fenner and Thompson 2005).

There is growing evidence to show that embryo growth in morphological dormancy seeds is strictly under the control of temperature; some of these species require a specific spectrum of light: dark photoperiods (Baskin and Baskin 2014a). For example, seeds of Areca triandra Roxb. require cold stratification at $4{ }^{\circ} \mathrm{C}$ to break dormancy and germinate quickly, but seeds subjected to warm stratification at $10-15{ }^{\circ} \mathrm{C}$ resulted in less germination (Yang et al. 2007). Furthermore, there is no shortage of studies to show that the speed of embryo growth in palms varies between species and temperature (see reviews in Broschat et al. 2014; Robinson 2009). As such, this further suggests that morphological dormancy holds the germination in check or controls the timing of germination.

Indeed, underdeveloped embryos are considered to be the ancestral dormancy class and other classes of dormancy have been hypothesized to have evolved from morphological dormancy or morphophysiological dormancy (Forbis et al. 2002; Willis et al. 2014). Thus, whether or not morphological dormancy is a form of dormancy is remarkably important because some of the palm species carry a multi-million years legacy of growing successfully in undisturbed, yet stable climates (Blach-Overgaard et al. 2013; Kissling et al. 2012). Their fine-tuned dormancy mechanisms allowed regional differences in diversity patterns. Climate change is already threatening several well-known or still undiscovered palm species (Blach-Overgaard et al. 2010). Defining dormancy class incorrectly or not defining kind of dormancy at all will likely result in applying improper empirical dormancy-breaking treatments leading to seed death, thereby obliterating valuable seeds available for storage and re-introductions.

Acknowledgments I am thankful to Prof. David Ward and an anonymous reviewer for their helpful suggestions on a previous version of the manuscript.

\section{Compliance with ethical standards}

Conflict of interest The author declares that he has no conflict of interest.

\section{References}

Baskin JM, Baskin CC (2004) A classification system for seed dormancy. Seed Science Research 14:1-16
Baskin CC, Baskin JM (2014a) Seeds: ecology, biogeography, and evolution of dormancy and germination. Elsevier, Second edn

Baskin JM, Baskin CC (2014b) What kind of seed dormancy might palms have? Seed Sci Res 24:17-22

Bewley JD, Bradford KJ, Hilhorst HW, Nonogaki H (2013) Environmental regulation of dormancy and germination Seeds, 3rd edition edn. Springer,

Blach-Overgaard A, Svenning JC, Dransfield J, Greve M, Balslev H (2010) Determinants of palm species distributions across Africa: the relative roles of climate, non-climatic environmental factors, and spatial constraints. Ecography 33:380-391

Blach-Overgaard A, Kissling WD, Dransfield J, Balslev H, Svenning J-C (2013) Multimillion-year climatic effects on palm species diversity in Africa. Ecology 94:2426-2435

Broschat TK (1998) Endocarp removal enhances Butia capitata (Mart.) Becc.(pindo palm) seed germination HortTechnology 8:586-587

Broschat T, Donselman H (1987) Effects of fruit maturity, storage, presoaking, and seed cleaning on germination in three species of palms. Journal of Environmental Horticulture 5:6-9

Broschat T, Elliott M, Hodel D (2014) Ornamental palms: biology and horticulture. Horticultural Reviews 42:1-120

Carpenter W (1988) Seed after-ripening and temperature influence Butia capitata germination. HortScience 23:702-703

Carpenter WJ, Ostmark ER, Cornell JA (1993) Embryo cap removal and high-temperature exposure-stimulate rapid germination of needle palm seeds. HortScience 28:904-907

Carvalho V, Ribeiro L, Lopes P, Agostinho C, Matias L, MercadanteSimões M, Correia L (2015) Dormancy is modulated by seed structures in palms of the cerrado biome. Australian Journal of Botany 63:444-454

Corner EJH (1966) The natural history of palms. Weidenfeld \& Nicolson, London

Fenner M, Thompson K (2005) The ecology of seeds. Cambridge Univ Press, Cambridge

Finch-Savage WE, Leubner-Metzger G (2006) Seed dormancy and the control of germination. New Phytol 171:501-523

Forbis TA, Floyd SK, Queiroz AD (2002) The evolution of embryo size in angiosperms and other seed plants: implications for the evolution of seed dormancy. Evolution 56:2112-2125

Henderson FM (2006) Morphology and anatomy of palm seedlings. Bot Rev 72:273-329

Hussey G (1958) An analysis of the factors controlling the germination of the seed of the oil palm, Elaeis guineensis (Jacq). Ann Bot 22:259 284

Kissling WD, Baker WJ, Balslev H, Barfod AS, Borchsenius F, Dransfield J, Govaerts R, Svenning JC (2012) Quaternary and preQuaternary historical legacies in the global distribution of a major tropical plant lineage. Glob Ecol Biogeogr 21:909-921

Kissling WD et al (2019) PalmTraits 1.0, a species-level functional trait database of palms worldwide. Scientific Data 6:1-13

Koebernik J (1971) Germination of palm seed. Principes 15:134-137

Long RL et al (2015) The ecophysiology of seed persistence: a mechanistic view of the journey to germination or demise. Biol Rev 90:3159

Mabberley DJ (2017) Mabberley's plant-book: a portable dictionary of plants, their classification and uses, vol Ed. 4. Cambridge University Press

Martin AC (1946) The comparative internal morphology of seeds the. Am Midl Nat 36:513-660

Mazzottini-dos-Santos HC, Ribeiro LM, Oliveira DMT (2018) Structural changes in the micropylar region and overcoming dormancy in Cerrado palms seeds. Trees 32:1415-1428

Medeiros MJ, Oliveira MT, Willadino L, Santos MG (2015) Overcoming seed dormancy using gibberellic acid and the performance of young Syagrus coronata plants under severe drought stress and recovery. Plant Physiol Biochem 97:278-286 
Meerow AW, Broschat TK (1991) Palm seed germination. Florida Cooperative Extension Service, Institute of Food and Agricultural

Moura ACF, Ribeiro LM, Mazzottini-dos-Santos HC, MercadanteSimões MO, Nunes YRF (2019) Cytological and histochemical evaluations reveal roles of the cotyledonary petiole in the germination and seedling development of Mauritia flexuosa (Arecaceae). Protoplasma 256:1299-1316

Nagao M, Kanegawa K, Sakai W (1980) Accelerating palm seed germination with gibberellic acid, scarification, and bottom heat. HortScience 15:200-201

Nazário P, Ferreira SADN, Borges EEDL (2017) Embryonic dormancy in seeds of Bactris gasipaes Kunth (peach-palm). J Seed Sci 39: $106-113$

Neves S, Ribeiro LM, da Cunha IRG, Pimenta MAS, Mercadante-Simões MO, Lopes PSN (2013) Diaspore structure and germination ecophysiology of the babassu palm (Attalea vitrivir) Flora-morphology. Distribution, Functional Ecology of Plants 208:68-78

Nikolaeva MG (1969) Physiology of deep dormancy in seeds

Oliveira N, Lopes P, Ribeiro L, Mercandante-Simões M, Oliveira L, Silvério F (2013) Seed structure, germination, and reserve mobilization in Butia capitata (Arecaceae). Trees 27:1633-1645

Orozco-Segovia A, Batis ANA, Rojas-Aréchiga M, Mendoza A (2003) Seed biology of palms: a review. Palms:47

Pérez HE (2009) Promoting germination in ornamental palm seeds through dormancy alleviation. HortTechnology 19:682-685

Pérez HE, Criley RA, Baskin CC (2008) Promoting germination in dormant seeds of Pritchardia remota (Kuntze) Beck., an endangered palm endemic to Hawaii. Nat Areas J 28:251-260

Ribeiro LM, Oliveira DMT, de Souza GQ (2012) Structural evaluations of zygotic embryos and seedlings of the macaw palm (Acrocomia aculeata, Arecaceae) during in vitro germination. Trees 26:851-863

Riffle RL, Craft P, Zona S (2012) The encyclopedia of cultivated palms, vol Ed. 2. Timber Press
Robinson M (2009) Cultivated palm seed germination. Univ Nevada Coop Ext SP-02-09

Schlindwein G, Schlindwein CCD, Dillenburg LR (2019) Seasonal cycle of seed dormancy controls the recruitment of Butia odorata (ARECACEAE) seedlings in savanna-like palm tree formations in southern Brazil. Austral Ecol 44:1398-1409. https://doi.org/10. 1111/aec.12813

Souza Dias D, Monteiro Ribeiro L, Sérgio Nascimento Lopes P, Aclécio Melo G, Müller M, Munné-Bosch S (2018) Haustorium-endosperm relationships and the integration between developmental pathways during reserve mobilization in Butia capitata (Arecaceae) seeds. Ann Bot 122:267-277. https://doi.org/10.1093/aob/mcy065

Tomlinson PB (1990) The structural biology of palms. Oxford University Press

Visscher AM, Castillo-Lorenzo E, Toorop PE, Junio da Silva L, Yeo M, Pritchard HW (2020) Pseudophoenix ekmanii (Arecaceae) seeds at suboptimal temperature show reduced imbibition rates and enhanced expression of genes related to germination inhibition. Plant Biol. https://doi.org/10.1111/plb.13156

Vleeshouwers L, Bouwmeester H, Karssen C (1995) Redefining seed dormancy: an attempt to integrate physiology and ecology. J Ecol: 1031-1037

Willis CG et al (2014) The evolution of seed dormancy: environmental cues, evolutionary hubs, and diversification of the seed plants. New Phytologist 203:300-309

Yang Q-H, Ye W-H, Yin X-J (2007) Dormancy and germination of Areca triandra seeds. Scientia Horticulturae 113:107-111

Publisher's note Springer Nature remains neutral with regard to jurisdictional claims in published maps and institutional affiliations. 